University of Nebraska - Lincoln

DigitalCommons@University of Nebraska - Lincoln

Papers in Biotechnology

Chemical and Biomolecular Engineering

Research and Publications

November 1997

\title{
Crossflow Microfiltration of Recombinant Escherichia coli Lysates after High Pressure Homogenization
}

Stuart M. Bailey

Department of Biological Systems Engineering, University of Nebraska,

Michael M. Meagher

Department of Chemical Engineering, University of Nebraska-Lincoln, mmeagher@unl.edu

Follow this and additional works at: https://digitalcommons.unl.edu/chemeng_biotechnology

Part of the Biochemical and Biomolecular Engineering Commons

Bailey, Stuart M. and Meagher, Michael M., "Crossflow Microfiltration of Recombinant Escherichia coli Lysates after High Pressure Homogenization" (1997). Papers in Biotechnology. 17.

https://digitalcommons.unl.edu/chemeng_biotechnology/17

This Article is brought to you for free and open access by the Chemical and Biomolecular Engineering Research and Publications at DigitalCommons@University of Nebraska - Lincoln. It has been accepted for inclusion in Papers in Biotechnology by an authorized administrator of DigitalCommons@University of Nebraska - Lincoln. 


\section{Abstract:}

Crossflow membrane filtration was used to process recombinant Escherichia coli cell lysates containing protein inclusion bodies after high pressure homogenization. The number of passes through the high pressure homogenizer changed the viscosities and average particle sizes of the cell lysates. The different cell lysates were processed with a hollow fiber unit containing microfiltration membranes and a plate and frame unit with either ultrafiltration or microfiltration membranes. There were differences in permeate flux and protein transmission for the various membranes with the best performing membranes giving permeate fluxes greater than $60 \mathrm{~L}$ $m-2 h_{-1}$ and protein transmissions greater than $90 \%$. For a given membrane, no differences were observed between the cell lysates following homogenization with one, two, and three passes at 83 $\mathrm{MPa}$. The lack of a difference between the three lysates is due to their similarities with respect to the released macromolecules and the presence of small $(<0.1 \mu \mathrm{m})$ cell debris.

Keywords: crossflow membrane filtration; Escherichia coli; high pressure homogenization; inclusion bodies

\section{INTRODUCTION}

Escherichia coli is widely used for the expression of mammalian and bacterial proteins. Overexpression of these recombinant proteins in E. coli often results in the formation of insoluble protein inclusion bodies (Marston, 1986). The first step in the recovery of the intracellular recombinant protein, whether soluble or insoluble, typically involves cell disruption. On a large scale, cell disruption is usually done with either a high pressure homogenizer or a bead mill (Engler, 1990; Kula and Schutte, 1987). Increasing the number of passes through a high pressure homogenizer causes greater protein release, but also results in smaller particle size distributions (Agerkvist and Enfors, 1990; Bailey et al., 1995; Middelberg et al., 1991; Titchener-Hooker et al., 1991). Smaller cell debris has a detrimental effect on subsequent downstream processing unit operations (Agerkvist and Enfors, 1990; Becker et al., 1983).

Recovery of intracellular protein from cell lysates is accomplished by either centrifugation (Clarkson et al., 1993; Titchener-Hooker et al., 1991) or crossflow membrane filtration (Le et al., 1984a, b; Meagher et al., 1994; Quirk and Woodrow, 1984). Models that describe membrane filtration indicate that the particle size of the material being processed influences the permeate flux. In cake filtration models, the permeate flux increases with the square of the particle diameter (Riesmeier et al., 1989; Tanaka et al., 1993). Other models for microfiltration have incorporated shear-induced diffusion or an inertial lift velocity to describe permeate flux (Davis, 1992). In each of these models, the permeate flux decreases with decreasing particle size. As a result of this emphasis on larger particle sizes to improve downstream processing, some investigations have focused on reducing the extent of homogenization (Bailey et al., 1995; Harrison et al., 1991; Vogels and Kula, 1992). There have been studies on the operational parameters required to recover proteins from cell lysate with crossflow membrane filtration (Gabler and Ryan, 1985; Le et al., 1984a, b). Some of these studies have used $E$. coli cell lysate containing inclusion bodies (Forman et al., 1990; Meagher et al., 1994). There has also been work on the relationship between increased homogenization and the centrifugal recovery of soluble protein from yeast (Clarkson et al., 1993) and inclusion bodies from E. coli lysate (Titchener-Hooker et al., 1991), but no one has published on the relationship between the number of passes through a high pressure homogenizer and crossflow membrane filtration. Because of the associated reduction in particle size, one would expect that increasing the extent of high pressure homogenization will result in diminished membrane filtration performance. Contrary to these expectations, we have found that, using operating conditions similar to those found in industrial downstream processing situations, increasing homogenization has little effect on the crossflow membrane filtration of E. Correspondence to: M. M. Meagher coli cell lysates.

\section{MATERIALS AND METHODS}

\section{Fermentation}

The strain of $E$. coli, the fermentation and induction conditions, and the harvest method were described earlier (Bailey

et al., 1995).

\section{Homogenization}

Frozen cells were resuspended to $100-150 \mathrm{~g} \mathrm{~L}^{-1}$ wet weight in buffer containing $50 \mathrm{~m} M$ Tris- $\mathrm{HCl}(\mathrm{pH} 8), 100 \mathrm{mM} \mathrm{NaCl}$, and $5 \mathrm{~m} M$ EDTA. Cell suspensions were stirred at $4{ }^{\circ} \mathrm{C}$ until thawed and then disrupted at $83 \mathrm{MPa}(12,000 \mathrm{psig})$ in a high pressure homogenizer (30 CD, APV Gaulin, Inc., Everett, MA). The cell suspensions were passed through the homogenizer up to 3 times and were cooled to less than $12^{\circ} \mathrm{C}$ between passes. Portions of the homogenized cells were removed after each pass and frozen at $-20^{\circ} \mathrm{C}$.

\section{Filtration Equipment}

Two filtration systems were used. System A consisted of a rotary positive displacement pump (Universal Pump Model 15, Waukesha Fluids, Delavan, WI) with a variable speed drive, a $0.19-\mathrm{m}^{2}$ cartridge heat exchanger (TBM Thermotech, Middleton, WI), and a 20-L retentate tank. Permeate flow rates were controlled with a needle valve (Cole- Parmer Instrument Co., Chicago, IL) and retentate back pressure was controlled with a sanitary diaphragm valve (model G695, Gemu Valves, Inc., Atlanta, GA). Inlet, outlet, and permeate pressures were measured using electronic pressure transducers (PX181, Omega Engineering, Stamford, CT). Acquisition of pressure data was performed using ACQUIRE software (Laboratory Technologies Corp., Wilmington, MA). System B was composed of a variable speed rotary lobe pump (model 1015, G \& H Products Corp., Menosha, WI), a $0.15-\mathrm{m}^{2}$ heat exchanger, and a jacketed, $75-\mathrm{L}$ stainless steel tank. Inlet and outlet pressures were measured with gauges (type S, Anderson Instrument Co., Fultonville, NY). Piping on both systems was a mixture of 316L stainless steel sanitary triclamp fittings and braided hose. In both systems, recirculation flow rates were measured with a magnetic flow meter (model 3115, Invalco, Combustion Engineering, Tulsa, $\mathrm{OK}$ ) and permeate flow rates were measured using a graduated cylinder and a stopwatch. A hollow fiber membrane unit with a $0.1-\mathrm{mm}$ pore size (Turbotube, A/G Technology, Needham, MA) was used with filtration system A. The hollow fiber unit contained nine polysulfone (PS) fibers with internal diameters of $3 \times 10^{-3} \mathrm{~m}$, lengths of 0.54 $\mathrm{m}$, and a total filtration area of $0.046 \mathrm{~m}^{2}$. A plate and frame unit (CONSEP, North Carolina SRT, Cary, NC) was used with filtration system B. The plate and frame unit separated the membranes into a total of 16 channels with heights of 0.5 
$\times 10^{-3} \mathrm{~m}$, widths of $1.5 \times 10^{-2} \mathrm{~m}\left(D_{h} 41 \times 10^{-3} \mathrm{~m}\right)$, and lengths of $0.14 \mathrm{~m}$. The total filtration area of the membranes in this unit was $0.034 \mathrm{~m}^{2}$. The following membrane chemistries and pore sizes were tested: $5 \times 10^{5} \mathrm{MWCO}$ polyvinylidene fluoride (PVDF) (Advanced

Membrane Technology, San Diego, CA), $0.1 \mathrm{~mm}$ polyethersulfone (PES) (Gelman Sciences, Ann Arbor, MI), $0.15 \mathrm{~mm}$ cellulose acetate (CA) (Schleicher \& Schuell, Keene, NH), and $0.2 \mathrm{~mm}$ PVDF (Tech-Sep, Cranbury, NJ).

\section{Membrane Operation}

Cell lysate was thawed and diluted to $40-60 \mathrm{~g} \mathrm{~L}^{-1}$ (based on initial wet weight of cells) in a buffer containing $150 \mathrm{mM} \mathrm{NaCl}, 20 \mathrm{~m} M$ Tris- $\mathrm{HCl}(\mathrm{pH} 8)$, and $2 \mathrm{~m} M$ EDTA. The physical characteristics of the cell lysates are presented in Table I. Following measurement of clean water fluxes, the water was drained from the system and 6-8 $\mathrm{L}$ of the cell lysate were added to the retentate tank. For the hollow fiber unit, the lysate was recirculated at $2.5 \times 10^{-4} \mathrm{~m}^{3} \mathrm{~s}^{-1}$ (axial velocity $44.0 \mathrm{~m} \mathrm{~s}^{-1}$ ) for 2-3 min before the permeate valve was opened to give the desired transmembrane pressure. The permeate valve was opened further after 1 and $2 \mathrm{~h}$ of filtration to give successively higher transmembrane pressures. For the flat sheet membranes in the plate and frame unit, the pump was started with the permeate completely open and the lysate was recirculated at $6.3 \times 10^{-4} \mathrm{~m}^{3} \mathrm{~s}^{-1}$ (axial velocity $45.3 \mathrm{~m} \mathrm{~s}^{-1}$ ). For both membrane systems

the permeates were returned to the retentate tanks (constant concentration). The lysate temperatures were maintained at $20 \pm$ $2^{\circ} \mathrm{C}$.

The membrane cleaning sequence involved rinsing with $30-40 \mathrm{~L}$ of distilled water at $25-30^{\circ} \mathrm{C}$, recirculating $10 \mathrm{~L}$ of a $100 \mathrm{ppm}$ hypochlorite for the $5 \times 10^{5}$ MWCO PVDF membranes, or 500 ppm hypochlorite for the $0.1 \mathrm{~mm}$ PS hollow fiber membranes at $25-30^{\circ} \mathrm{C}$ and $3.0 \times 10^{-4} \mathrm{~m}^{3} \mathrm{~s}^{-1}$ for $2-5 \mathrm{~h}$ followed by rinsing with 30-40 L distilled water. The extent of cleaning was done by comparing the clean water flux with the initial clean water flux of the membrane. The hollow fiber membrane unit and the $5 \times 10^{5}$ MWCO PVDF membranes were reused for further experiments after cleaning.

Table 1 Coll tyate tharaseoritics.

\begin{tabular}{|c|c|c|c|c|}
\hline $\begin{array}{l}\text { Wo } \\
\text { Corses }\end{array}$ & 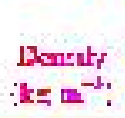 & $\begin{array}{l}\text { Vi=crity } \\
\text { a: } 20 \mathrm{~s}^{-1} \\
(\mathrm{col} / 2 \mathrm{~s})\end{array}$ & [Nin, & 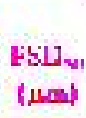 \\
\hline - & 1321 & LUU & $v \_v$ & 4.33 \\
\hline 2 & 130 & Ly4 & $-x\rfloor$ & 2.14 \\
\hline 3 & IJI0 & L]I & עلـ & 2.12 \\
\hline
\end{tabular}

Above Table shows: Particle size in the cell lysate was measured by scanning electron microscopy. PSD 10 indicates that $10 \%$ of the total number of measured particles were smaller than this size. PSD50 indicates that $50 \%$ of the total number of measured particles were smaller than this size.

\section{Membrane Efficiency}

Transmembrane pressure (TMP) was calculated from Equation (1):

$$
\mathrm{TMP}=\frac{P_{\text {in }}+P_{\text {out }}}{2}-P_{\text {perm }},
$$

where $P^{\text {in }}$ is the inlet pressure, $P^{\text {out }}$ is the outlet pressure, and $P^{\text {perm }}$ is the permeate pressure. Retentate and permeate samples $(1 \mathrm{~mL})$ were centrifuged at $16,000 \mathrm{~g}$ for $8 \mathrm{~min}$ in an Eppendorf 5415C centrifuge. This was done for the permeate samples to insure that no solids had passed through the membranes. Protein transmission $(\% T)$ was determined by measuring the soluble protein in the clarified supernatants of the retentate and permeate samples. Two methods were used to measure protein transmission: a commercial version (BioRad Laboratories, Hercules, CA) of the Bradford protein assay (Bradford, 1976) and the ultraviolet absorbance at 280 $\mathrm{nm}$. Protein transmission with either method was calculated using the equation.

$$
\% T=\frac{P \text { ermeate absorbance }}{\text { retentate absorbance }} \times 100 \%
$$

\section{Electrophoresis}

Centrifuged retentate and permeate samples for discontinuous SDS-PAGE were run on $12 \%$ acrylamide gels as described by Laemmli (1970). The supernatants from the retentate and permeate samples were resuspended in sample buffer to final concentrations of $62.5 \mathrm{mM}$ Tris- $\mathrm{HCl}(\mathrm{pH} 6.8)$, $10 \%$ glycerol, $5 \%$ b-mercaptoethanol, $2 \%$ SDS, and $0.01 \%$ bromophenol blue. The areas of the protein bands in the Coomassie blue stained gels were analyzed using Gel-Base software (UVP Inc., San Gabriel, Calif.).

\section{RESULTS}

\section{Membrane Performance over Time}

Permeate flux and protein transmission decreased over the course of the various experiments. Figure 1 shows typical permeate flux time and protein transmission time curves for the $0.1-\mathrm{mm}$ hollow fiber membrane with the cell lysate after one pass through the homogenizer. The sharp initial decline in permeate fluxes after an increase in TMP followed by periods of relatively constant flux is common to many membrane filtration processes (Davis, 1992; Le and Gollan, 1989; Le et al., 1984a, b; Riesmeier et al., 1989). Following a hange in TMP, there was not much change in either the permeate flux or the protein transmission between the first samples taken in the initial 5 and $15 \mathrm{~min}$ and the samples taken after $1 \mathrm{~h}$. Other studies with cell lysates also reached quasi-steady-state permeate fluxes in less than $30 \mathrm{~min}$ (Le and Gollan, 1989; Le et al., 1984a, b; Gabler and Ryan, 1985). As was observed in earlier studies, we found that the membrane pore size had little effect on the declines of the permeate fluxes and the protein transmissions (McDonogh et al., 1992). Curves similar to those in Figure 1 were also obtained for the other membranes used in these studies. The permeate flux and protein transmission data at the 1-h time period were used for comparative purposes between the different membranes and cell lysates.

\section{Effect of Number of Passes Hollow Fiber Membranes}

Cell lysates after one, two, and three passes through the homogenizer were processed with the $0.1-\mathrm{mm}$ hollow fiber membranes at TMPs of $27.6,62.1$, and $82.7 \mathrm{kPa}$. For the three TMPs, the permeate fluxes are shown in Figure $2 \mathrm{a}$ and 
the protein transmissions are shown in Figure $2 b$. The permeate fluxes increased steadily with increasing TMP up to a maximum of $25-35 \mathrm{~L} \mathrm{~m}^{-2} \mathrm{~h}^{-1}$ at TMPs greater than $62.1 \mathrm{kPa}$ (Fig. 3). The protein transmissions for the cell lysate disrupted in one pass at $83 \mathrm{MPa}$, as measured with the dye binding assay, decreased with increasing TMP from $37 \pm 8 \%$ (degrees of freedom, df44) at $27.6 \mathrm{kPa}$ to $20 \pm$ $7 \%$ (df 4 3) at $82.7 \mathrm{kPa}$ (Fig. 3). Transmissions of $\mathrm{UV}^{280}$ absorbing material ranging from $90 \%$ at a TMP of $27.6 \mathrm{kPa}$ to $65 \%$ at a TMP of $82.7 \mathrm{kPa}$ were measured using the ultraviolet absorbance at $280 \mathrm{~nm}$. The pattern of decreasing transmission with increasing TMP was also observed for the cell lysates disrupted in two and three passes. Analysis of the permeate relative to the retentate by SDSPAGE indicated that as the molecular weight of the proteins increased, the amount in the permeate decreased (Figs.

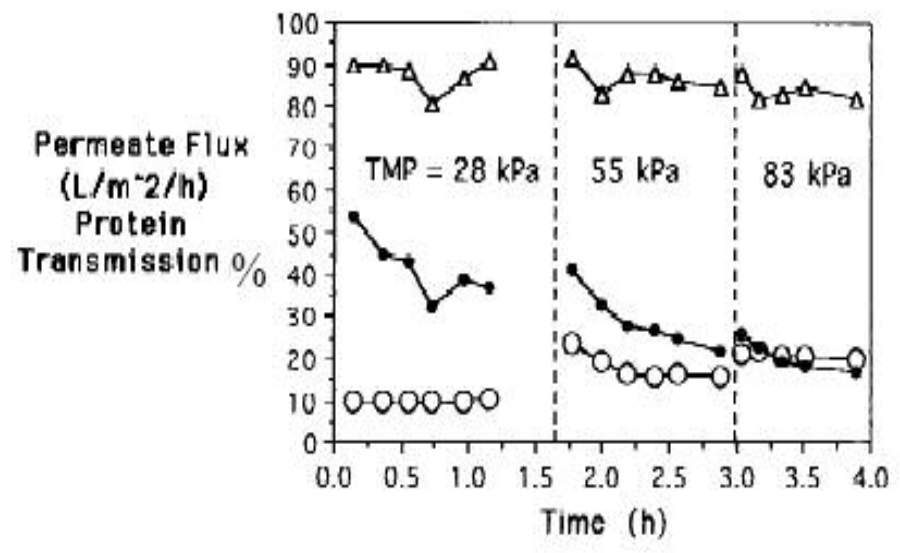

4,5). Above a molecular weight of approximately $80 \mathrm{kDa}$ there were no measurable bands in the permeate samples. This size exclusion effect was more pronounced for the higher TMP sample such that even smaller molecular weight proteins were inhibited from passing through the cake layer and

Figure (1). (s) The rates of permeate flux, (n) UV 280 -absorbing material transmission, and (d) dye-binding protein transmission decline using the 0.1-mm PS hollow fiber membranes. Cell lysate was produced after one pass at $83 \mathrm{MPa}$. The transmembrane pressure was increased in three steps
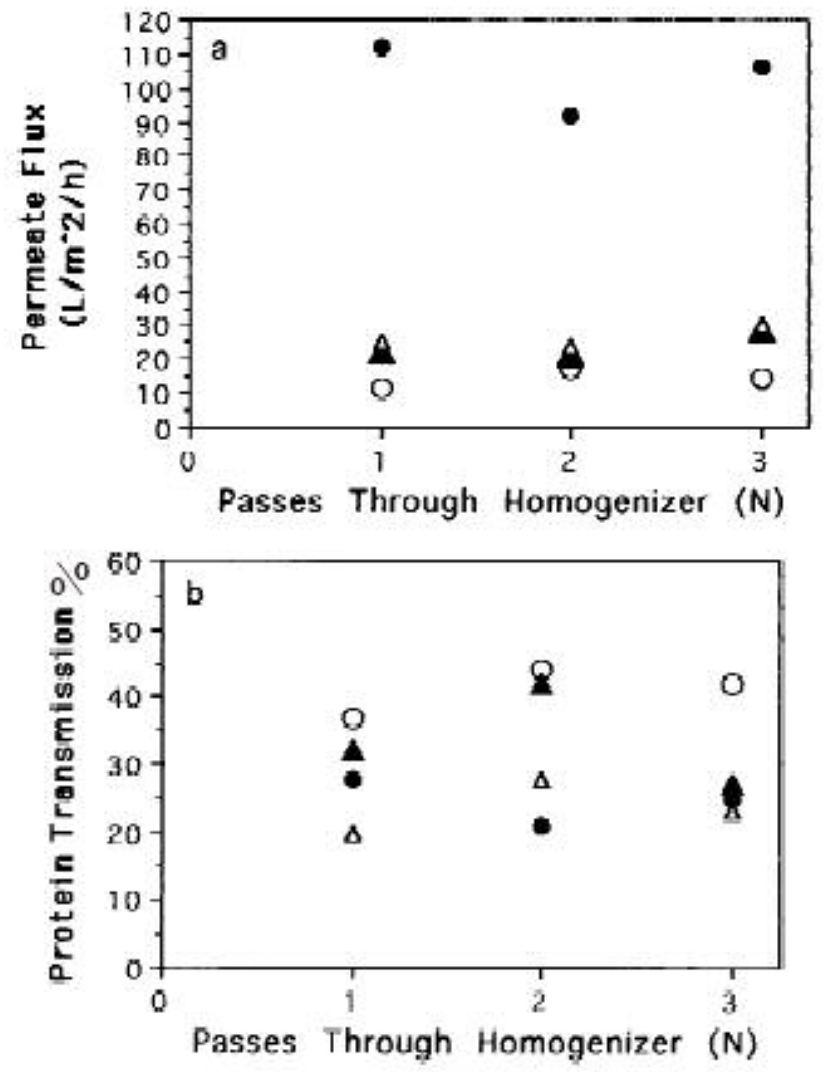

from 28 to $55 \mathrm{kPa}$ and then $83 \mathrm{kPa}$.

Figure 2. The effect of the number of passes through the high pressure homogenizer on (a) the permeate flux and (b) the dye-binding protein transmission. The 0.1-mm PS hollow fiber membranes were run at (s) 27.6 $\mathrm{kPa},(\mathrm{m}) 62.1 \mathrm{kPa}$, and (n) $82.7 \mathrm{kPa}$. An average operating TMP of 76.4 $\mathrm{kPa}$ was used with the (d) $5 \times 10_{5}$ MWCO PVDF membranes.

the membrane pores (Fig. 4). Increasing the number of passes through the high pressure homogenizer did not change the protein size exclusion effect of the cake layer because the same protein profiles are visible in each of the cell lysates (Fig. 5).

Figure 3. The effect of TMP on the permeate flux (unfilled symbols) and the dye-binding protein transmission (filled symbols) using the 0.1-mm PS hollow fiber membranes. The cell lysates were used in the membrane filtration experiments after (s) one, (n) two, and (h) three passes through the high pressure homogenizer.
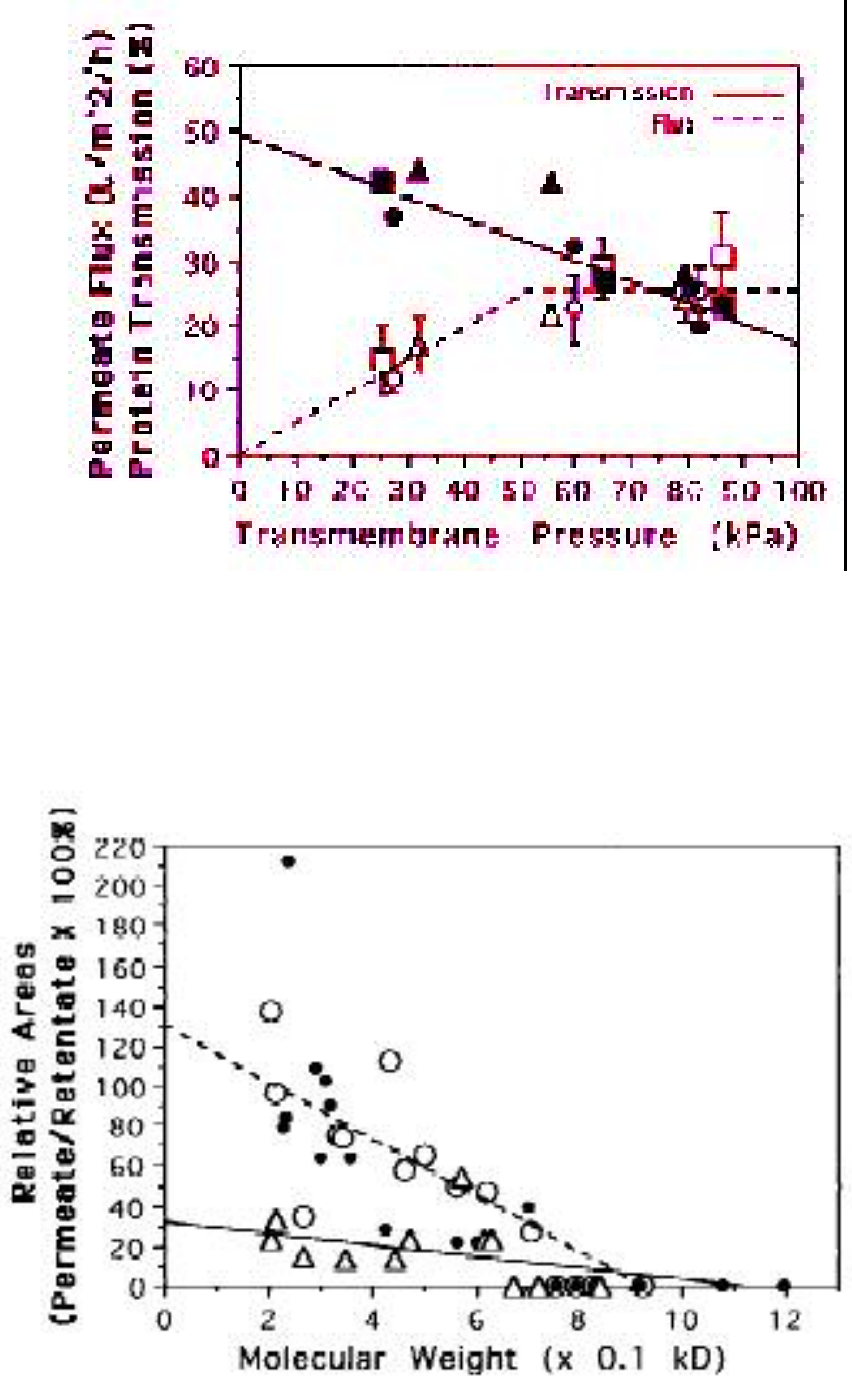

Figure 4. The effect of TMP on the retention of different molecular weight proteins using the $0.1-\mathrm{mm}$ PS hollow fiber membranes. The cell lysates ( $N 41$ ) were filtered with transmembrane pressures of (s) 27.6 $\mathrm{kPa}$, (d) $62.1 \mathrm{kPa}$, and (n) $82.7 \mathrm{kPa}$. The straight line is for the 27.6 and $62.1 \mathrm{kPa}$ samples and the dashed line is for the $82.7 \mathrm{kPa}$ sample. The areas from the scanned retentate and permeate samples on an SDS-PAGE gel 


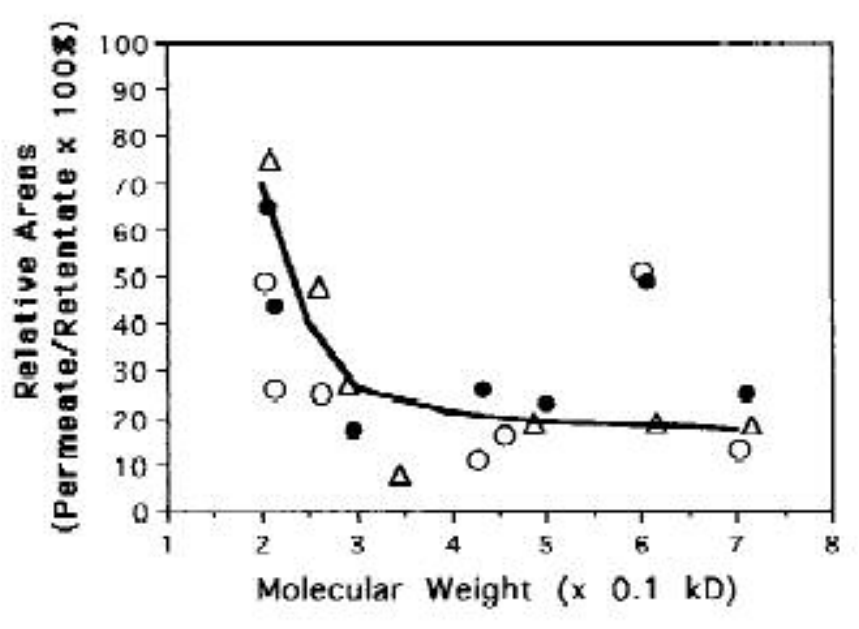

were compared for proteins of the same molecular weight.

Figure 5. The effect of the number of homogenizer passes on the retention of different molecular weight proteins using the $0.1-\mathrm{mm}$ PS hollow fiber membranes at a TMP of $27.6 \mathrm{kPa}$. The cell lysates were used in the membrane filtration experiments after $(\circ)$ one, $(\bullet)$ two, or $(\Delta)$ three passes through the homogenizer at $83 \mathrm{MPa}$. The areas from the scanned retentate and permeate samples on an SDS-PAGE gel were compared for

proteins of the same molecular weight.

mm PVDF membranes, there was little difference between the permeate fluxes measured for cell lysates disrupted in one and three passes. When a $0.1-\mathrm{mm}$ PES membrane was used, the permeate fluxes measured for cells homogenized with one pass were higher than the permeate fluxes measured for cells homogenized with three passes. This difference could be due to the limited number of runs made. For all three of these membranes the protein where $J^{\text {prot }}$ is the protein flux $\left(\mathrm{kg} \mathrm{m}^{-2} \mathrm{~h}^{-1}\right), J$ is the permeate flux $\left(\mathrm{L} \mathrm{m}^{-2} \mathrm{~h}^{-1}\right), \% T$ is the percent protein transmission from Equation (2), and $C$ is the initial protein concentration $\left(\mathrm{kg} \mathrm{m}^{-3}\right)$. There was no significant difference between the protein fluxes at the different TMPs for the cell lysates disrupted in one, two, and three passes through the homogenizer.

\begin{tabular}{llllllr}
\hline & \multicolumn{2}{c}{$\begin{array}{c}\text { Pore size TMP } \\
\text { Chemistry }\end{array}$} & $\begin{array}{c}\text { Flux } \\
(\mu \mathrm{m})\end{array}$ & $(\mathrm{kPa})$ & \multicolumn{3}{c}{ Transmission No. } & $\left(\mathrm{L} \mathrm{m}^{-2} \mathrm{~h}^{-1}\right)$ & $(\%)$ & runs \\
\hline PES & 0.1 & 73.1 & 1 & 68 & 90 & 2 \\
PES & 0.1 & 75.8 & 3 & 37 & 89 & 1 \\
CA & 0.15 & 75.8 & 1 & 62 & 96 & 1 \\
CA & 0.15 & 89.6 & 3 & 54 & 94 & 1 \\
PVDF & 0.2 & 65.5 & 1 & 89 & 36 & 1 \\
PVDF & 0.2 & 74.1 & 3 & 89 & 23 & 2 \\
\hline
\end{tabular}

However, it appears that there is a possible nonlinear relationship between protein flux and TMP with the highest protein flux values located between 50 and $60 \mathrm{kPa}$ (Fig. 6). This apparent maximum of protein flux corresponds to the beginning of the permeate flux-TMP plateau in Figure 3, as well as the minimum in specific cake resistance reported in other studies (Baker et al., 1985; Riesmeier et al., 1989). transmissions were relatively unchanged by increasing the extent of homogenization of the cell lysate.

\section{DISCUSSION}

\section{Comparison of Membrane Performance}

The permeate flux-TMP curve shown in Figure 3 for the hollow fiber unit is typical of many ultrafiltration and microfiltration processes (Forman et al., 1990; Le et al., 1984a; Riesmeier et al., 989). In microfiltration, a cake layer is deposited as the permeate flux ncreases with increasing TMP (Baker et al., 1985; Le and Gollan, 1989; Riesmeier et al., 1989; Tanaka et al., 1993). Once a critical TMP is reached the cake thickness remains constant, but the cake becomes increasingly compacted with higher TMPs. The increasing specific resistance of the compacted cake layer negates any positive effect that TMP has on the permeate flux (Baker et al., 1985; Riesmeier et al., 1989). The maximum permeate fluxes of $25-35 \mathrm{~L} \mathrm{~m}^{-2} \mathrm{~h}^{-1}$ using the hollow fiber unit (Fig. 3) are comparable to permeate fluxes reported for the removal of soluble protein from $E$. coli cell lysates (Gabler and Ryan, 1985; Meagher et al., 1994) and the recovery of an intracellular enzyme from lysed Pseudomonas fluorescens (Le et al., 1984a). Le and Gollan (1989) reported a permeate flux of $60 \mathrm{~L} \mathrm{~m}^{-2} \mathrm{~h}^{-1}$ for the recovery of an intracellular malate dehydrogenase from a low initial concentration $\left(0.9 \mathrm{~g} \mathrm{~L}^{-1}\right)$ of lysed yeast cells. Higher permeate fluxes $\left(>60 \mathrm{~L} \mathrm{~m}^{-2} \mathrm{~h}^{-1}\right)$ were achieved with a variety of membrane pore sizes and chemistries in the plate and frame configuration (Fig. 2a, Table II). Although the flow in the hollow fiber unit was turbulent for each cell lysate (5300 $<\operatorname{Re}<8000$ ), the higher permeate fluxes with the plate and

$$
J_{\text {prot }}=J C \% T / 100,
$$

frame configuration $(2800<\operatorname{Re}<4300)$ were probably due to the higher shear stresses at the cake surface associated with the narrower channels (Lu et al., 1993). With the hollow fiber unit, the protein transmission decreased with increasing TMP (Fig. 3). This trend has been reported for some studies (Forman et al., 1990; Kroner et al., 1987; Meagher et al., 1994; Sheehan et al., 1990), but not by groups that used high TMPs with large pore size membranes (Gabler and Ryan, 1985; Le et al., 1984a, b). The hollow fiber protein transmissions were similar to data from the crossflow membrane filtration of various cell lysates (Kroner et al., 1987 ) and the separation of soluble proteins from $E$. coli cell lysates containing inclusion bodies (Meagher et al., 1994). At the higher TMPs $(\$ 60 \mathrm{kPa})$, the hollow fiber protein transmissions were similar to those measured for the $5 \times 10^{5}$ MWCO PVDF (Fig. 2b) and 0.2-mm PVDF membranes (Table II). The protein transmissions through the $0.1-\mathrm{mm}$ PES and $0.15-\mathrm{mm}$ CA membranes were greater than $90 \%$, which is similar to the results reported for the separation of soluble protein from cell debris with large pore size $(\$ 0.45$ 
mm) membranes at high TMPs (Gabler and Ryan, 1985; Le et al., $1984 a, b)$ and for extracellular protein recovery (Le and Gollan, 1989; Sheehan et al., 1990). We used the product of percent transmission and permeate flux, referred to as the protein flux, to determine the best operating TMP for the hollow fiber unit (Fig. 6):

Figure 6. The effect of the number of homogenizer passes and TMP on the protein flux using the $0.1-\mathrm{mm}$ PS hollow fiber membranes. The cell lysates were used in the membrane filtration experiments after (o) one, (•) two, and $(\Delta)$ three passes through the homogenizer.

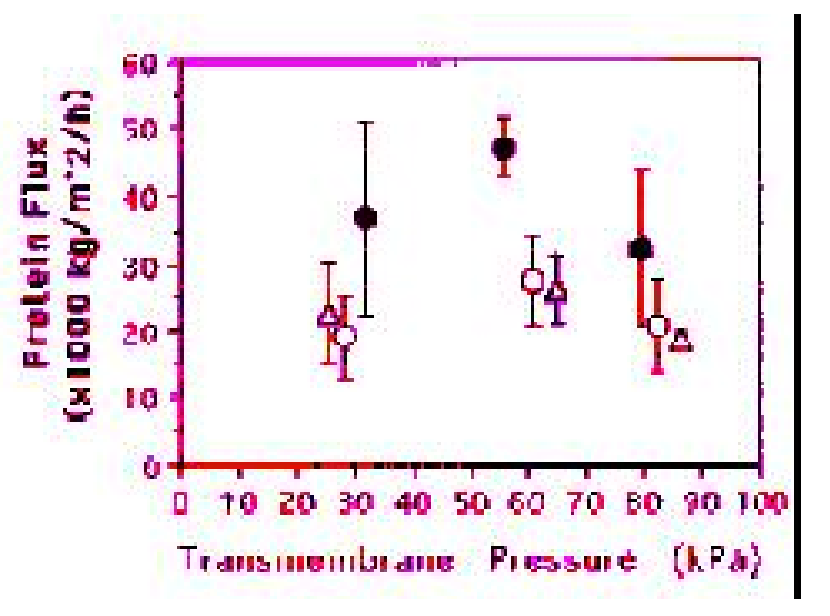

Our result is in contrast to previous studies that have suggested that operating at a low TMP gives the best results for the membrane filtration of cell lysates (Dorin et al., 1990; Forman et al., 1990; Meagher et al., 1994). The protein fluxes for the $5 \times 10^{5}$ MWCO membranes and an initial protein concentration of $4.1 \mathrm{~kg}$ $\mathrm{m}^{-3}$ were $0.13 \mathrm{~kg} \mathrm{~m}^{-2} \mathrm{~h}^{-1}$ after one pass through the homogenizer, $0.08 \mathrm{~kg} \mathrm{~m}^{-2} \mathrm{~h}^{-1}$ after two passes, and $0.09 \mathrm{~kg} \mathrm{~m}^{-2} \mathrm{~h}^{-1}$ after three passes. The protein fluxes for the three membranes in Table II ranged from a low of $0.08 \mathrm{~kg} \mathrm{~m}^{-2} \mathrm{~h}^{-1}$ for the $0.2-\mathrm{mm}$ PVDF membrane to $0.23 \mathrm{~kg} \mathrm{~m}^{-2} \mathrm{~h}^{-1}$ for the PES and CA membranes. Because earlier studies used $E$. coli cell lysates at a concentration of $100 \mathrm{~g} \mathrm{~L}^{-1}$, the initial protein concentration is assumed to be double that found with our initial cell concentration of $50 \mathrm{~g} \mathrm{~L}^{-1}$ at $7.8 \mathrm{~kg} \mathrm{~m}^{-3}$. The highest calculated protein fluxes were $0.11 \mathrm{~kg} \mathrm{~m}^{-2}$ $\mathrm{h}^{-1}$ Meagher et al., 1994) and $0.02 \mathrm{~kg} \mathrm{~m}^{-2} \mathrm{~h}^{-1}$ (Forman et al., 1990), both of hich are substantially lower than the best protein fluxes reported here. Comparable protein fluxes were calculated from the data for 0.45-mm flat sheet membranes (Le et al., 1984a, b) and a 0.2-mm TFE rotary shear filter (Kroner et al., 1987).

\section{Effect of Increasing Homogenization}

There were differences in the average particle sizes and viscosities of the cell lysates after one, two, and three passes through the homogenizer (Table I). Using the various membrane filtration models, one would expect that the differences in the cell lysates would lead to differences in the permeate fluxes. However, few differences were found between the permeate fluxes and protein transmissions for the three cell lysates for each of the membranes that were tested. The use of lower crossflow velocities and lysate concentrations may reveal differences between the lysates (Tarleton and Wakeman, 1993), but such conditions would probably not be industrially useful. There are important similarities among the cell lysates that are either not included in microfiltration models or are

not easily measured. Of particular interest are the extensive release of macromolecules and the presence of small cell debris. Cell lysate is composed of macromolecules as well as particulate cell debris (Agerkvist and Enfors, 1990; Harrison et al., 1991; Kula and Schutte, 1987). Proteins are known to bind to microfiltration and ultrafiltration membranes with negative consequences (Bowen and Gan, 1991; Nilsson, 1990). Junker et al. (1994) correlated decreasing membrane performance with the increasing suspended solids concentration of media used for $E$. coli fermentations. McDonogh et al. (1992) showed that the quasi-steady-state permeate fluxes for a suspension of yeast cells and the same suspension with the cells removed were identical within 60 min of the commencement of filtration. Solutions of proteins containing aggregates were responsible for declining permeate fluxes during stirred cell microfiltration (Bowen and Gan, 1991; Kelly et al., 1993). These studies all show the importance of proteins and other suspended solids in effecting embrane performance during crossflow filtration. Although no one has yet tested the extent of binding of cell lysate components other than proteins to various membranes, it can be assumed that these macromolecules will also bind to membrane surfaces and pores. The presence of a single layer of bacteria with its associated extracellular matrix containing proteins and polysaccharides determined the cake resistance and the solute rejection during dead-end microfiltration (Hodgson et al., 1993). Other macromolecules used as antifoams have been shown to bind to membrane surfaces and diminish membrane performance (Kroner et al., 1986). Clearly, the presence of macromolecules, which are inherently abundant in cell lysates, have a negative effect on membrane filtration. The average size of the cell debris for the lysates decreased with increasing homogenization (Table I), but all three lysates had a large number of particles less than $0.1 \mathrm{~mm}$ that were not measured. This similarity between the presence of small particles in the cell lysates is important because the smaller particles in polydisperse suspensions are responsible for the declines in permeate flux during membrane filtration (Nagata et al., 1989; Tanaka et al., 1993; Tarleton and Wakeman, 1993). Therefore, we can expect that the smaller particles in the cell lysates were more important in limiting the performance of the membranes than the average or larger sized particles. The high crossflow velocities used with both membrane systems would be expected to produce similar high resistance cake layers because the smaller particles in the lysates would be preferentially deposited in the uppermost layers of the cakes (Lu and Ju, 1989; Tanaka et al., 1993; Tarleton and Wakeman, 1993). Filter cakes formed from these smaller particles would then have a higher cake resistance than would be expected from calculations based on the average particle size of the suspension being processed.

Another indication, other than the permeate fluxes and protein transmissions, that the cake layers formed by the three lysates were similar are the protein rejection profiles in Figure 5. There is little visible difference in the size exclusion effect between the three cell lysates processed with the hollow fiber unit, indicating that the cake layers probably have similar compositions and porosities. Although no size exclusion effect was found during the removal of soluble protein from E. coli lysates using low TMPs (Forman et al., 
1990; Meagher et al., 1994), other groups have shown that the recovery of protein from cell lysates decreases as the molecular weight increases (Kroner et al., 1987; Quirk and Woodrow, 1984). For soluble proteins, the presence of a size exclusion effect may actually promote selective purification of low molecular weight recombinant proteins by removing medium and high molecular weight proteins during recovery.

\section{CONCLUSIONS}

Cell lysates are complex systems that are inherently difficult to process because of their size and composition polydispersity. Although it is true that fewer passes through thehomogenizer will give particle distributions with larger average particle sizes, a single pass of recombinant $E$. coli through a high pressure homogenizer at $83 \mathrm{MPa}$ releases enough macromolecules and smaller cell debris (\#0.1 mm) to make further passes indistinguishable in terms of their crossflow membrane filtration performance. The performance of some of the membranes in the plate and frame membrane system compare favorably with the results from previous crossflow membrane filtration studies on the recovery of intracellular proteins from cell debris. A direct comparison is difficult due to the myriad process conditions used in earlier studies, but the combination of permeate fluxes greater than $60 \mathrm{~L} \mathrm{~m}-2 \mathrm{~h}-1$ and protein transmissions greater than $90 \%$ that were achieved with the 0.15 -mm CA and 0.1-mm PES membranes were notable.

\section{References}

Agerkvist, I., Enfors, S.-O. 1990. Characterization of E. coli cell disintegrates from a bead mill and high pressure homogenizers. Biotechnol. Bioeng. 36: 10831089 .

2 .Bailey, S. M., Blum, P., Meagher, M. M. 1995. Improved homogenization of recombinant Escherichia coli following pretreatment with guanidine HCl. Biotechnol. Prog. 11: 533-539.

Baker, R. J., Fane, A. G., Fell, C. J. D., Yoo, B. H. 1985. Factors affecting flux in crossflow filtration. Desalination 53: 81-93.

Becker, T., Ogez, J. R., Builder, S. E. 1983. Downstream processing of proteins. Biotechnol. Adv. 1: 247-261.

Bowen, W. R., Gan, Q. 1991. Properties of microfiltration membranes: Flux loss during constant pressure permeation of bovine serum albumin. Biotechnol. Bioeng. 38: 688-696.

Bradford, M. M. 1976. A rapid and sensitive method for the quantitation of microgram quantities of protein utilizing the principle of protein-dye binding. Anal. Biochem. 72: 248-252.

Clarkson, A. I., Lefevre, P., Titchener-Hooker, N. J. 1993. A study of process interactions between cell disruption and debris clarification stages in the recovery of yeast intracellular products. Biotechnol. Prog. 9: $462-467$.

Davis, R. H. 1992. Modeling of fouling of cross-flow microfiltration membranes. Separation Purif. Methods 21: 75-126.

Dorin, G., Thomson, J., Hanisch, W. 1990. Fractionation of recombinant tumor necrosis factor using hydrophobic and hydrophilic membranes. Biotechnol. Prog. 6: 494-497.

Engler, C. R. 1990. Cell disruption by homogenizer, pp. 95-105. In: J. A. Asenjo (ed.), Separation processes in biotechnology. Marcel Dekker, New York

Forman, S. M., DeBernardez, E. R., Feldberg, R. S., Swartz, R. W. 1990. Crossflow filtration for the separation of inclusion bodies from soluble proteins in recombinant Escherichia coli cell lysate. J. Membr. Sci. 48: 263-279.

Gabler, R., Ryan, M. 1985. Processing of cell lysate with tangential flow filtration. ACS Symp. Ser. 271: 1-20.

Harrison, S. T. L., Chase, H. A., Dennis, J. S. 1991. Combined chemical and mechanical processes for the disruption of bacteria. Bioseparation 2: $95-105$.

Hodgson, P. H., Leslie, G. L., Schneider, R. P., Fane, A. G., Fell, C. J. D., Marshall, K. C. 1993. Cake resistance and solute rejection in bacterial microfiltration: The role of the extracellular matrix. J. Membr. Sci. 79: $35-53$.
Junker, B. H., Timberlake, S., Bailey, F. J., Reddy, J., Prud'homme, R., Gbewonyo, K. 1994. Influence of strain and medium composition on filtration of Escherichia coli suspensions. Biotechnol. Bioeng. 44: 539-548.

Kelly, S. T., Opong, W. S., Zydney, A. L. 1993. The influence of protein aggregates on the fouling of microfiltration membranes during stirred cell filtration. J. Membr. Sci. 80: 175-187.

Kroner, K. H., Hummel, W., Volkel, J., Kula, M.-R. 1986. Effects of antifoams on cross-flow filtration of microbial suspensions, pp. 223-232. In: E. Drioli and M. Nakagaki (eds.), Membranes and membrane processes. Plenum Press, New York.

Kroner, K. H., Nissinen, V., Ziegler, H. 1987. Improved dynamic filtration of microbial suspensions. Bio/Technology 5: 921-926.

Kula, M.-R., Schutte, H. 1987. Purification of proteins and the disruption of microbial cells. Biotechnol. Prog. 3: 31-42.

Laemmli, U. K. 1970. Cleavage of structural proteins during the assembly of the head of bacteriophage T4. Nature (London) 227: 680-685.

Le, M. S., Gollan, K. L. 1989. Fouling of microporous membranes in biological

applications. J. Membr. Sci. 40: 231-242.

Le, M. S., Spark, L. B., Ward, P. S. 1984a. The separation of aryl acylamidase

by cross flow microfiltration and the significance of enzyme/ cell debris interaction. J. Membr. Sci. 21: 219-232.

Le, M. S., Spark, L. B., Ward, P. S., Ladwa, N. 1984b. Microbial asparaginase

recovery by membrane processes. J. Membr. Sci. 21: 307-319.

Lu, W.-M., Ju, S.-C. 1989. Selective particle deposition in crossflow filtration.

Separation Sci. Technol. 24: 517-540.

Lu, W.-M., Hwang, K.-J., Ju, S.-C. 1993. Studies on the mechanism of cross-flow filtration. Chem. Eng. Sci. 48: 863-872.

Marston, F. A. O. 1986. The purification of eukaryotic polypeptides synthesized

in Escherichia coli. Biochem. J. 240: 1-12.

McDonogh, R. M., Bauser, H., Stroh, N., Chmiel, H. 1992. Separation

efficiency of membranes in biotechnology: An experimental and mathematical

study of flux control. Chem. Eng. Sci. 47: 271-279.

Meagher, M. M., Bartlett, R. T., Rai, V. R., Khan, F. R. 1994. The extraction of rIL-2 inclusion bodies from Escherichia coli using cross-flow filtration. Biotechnol. Bioeng. 43: 969-977.

Middelberg, A. P. J., O’Neill, B. K., Bogle, I. D. L., Snoswell, M. A. 1991. A novel technique for the measurement of disruption in high-pressure homogenization: Studies on E. coli containing recombinant inclusion bodies. Biotechnol. Bioeng. 38: 363-370.

Nagata, N., Herouvis, K. J., Dziewulski, D. M., Belfort, G. 1989. Crossflow membrane microfiltration of a bacterial fermentation broth. Biotechnol. Bioeng. 34: 447-466.

Nilsson, J. L. 1990. Protein fouling of UF membranes: Causes and consequences.

J. Membrane Sci. 52: 121-142.

Quirk, A. V., Woodrow, J. R. 1984. Investigation of the parameters affecting the separation of bacterial enzymes from cell debris by tangential flow filtration. Enzyme Microb. Technol. 6: 201-206.

Riesmeier, B., Kroner, K. H., Kula, M.-R. 1989. Tangential filtration of microbial suspensions: Filtration resistances and model development. J. Biotechnol. 12: 153-172.

Sheehan, J. J., Hamilton, B. K., Levy, P. F. 1990. Pilot-scale membrane filtration process for the recovery of an extracellular bacterial protease. ACS Symp. Ser. 419: 130-155.

Tanaka, T., Kamimura, R., Itoh, K., Nakanishi, K., Matsuno, R. 1993. Factors affecting the performance of crossflow filtration of yeast cell suspension. Biotechnol. Bioeng. 41: 617-624.

Tarleton, E. S., Wakeman, R. J. 1993. Understanding flux decline in crossflow microfiltration: Part I-Effects of particle and pore size. Trans. Inst. Chem. Eng., Part A, 71: 399-410.

Titchener-Hooker, N. J., Gritsis, D., Mannweiler, K., Olbrich, R., Gardiner, S. A. M., Fish, N. M., Hoare, M. 1991. Integrated process design for producing and recovering proteins from inclusion bodies. BioPharm 4(4): 34-38.

Vogels, G., Kula, M.-R. 1992. Combination of enzymatic and/or thermal pretreatment with mechanical cell disruption. Chem. Eng. Sci. 47: $123-131$. 